\title{
Field Notes
}

Conference: Concepts of Conflict and Concord in Russian and European History, September 2019, Ekaterinburg, Russia

On 3-4 September 2019 the Ural Humanities Institute of the Ural Federal University (Ekaterinburg, Russian Federation) sponsored an international conference, "Concepts of Conflict and Concord in Russian and European History." The organizers were Professors James White and Sergei Sokolov, and their intent is to co-edit a volume of essays based on papers from this conference and related proceedings under the conflict and concord rubric. There were five panels, each with two-three participants reading papers in Russian or English. Topics ranged from "Conflict, Concord, and the Theory of Colonial Revolution" (Konstantin Bugrov, Ural Federal University), to "How the Anti-Slavery Movement in the West Influenced those Involved with the Liberation of Serfs in Russia" (Shane O'Rourke, York University, UK), and on to "Conflicted Loyalties: Emperor Nicholas II and His Imperial High Command, February 1917” (Bruce Menning, University of Kansas).

ASEEES Conference: November, 2019, San Francisco, California - Program Highlights

A.

"Cold War Citizen Diplomacy"

Discussant: Lyubov Ginzburg, Independent Scholar

Chair: Jennifer Hudson, U of Texas at Dallas

The Belief in Soviet-American Musical Encounters During the Cold War Meri Herrala, U of Helsinki (Finland);

Official, Professional, and Personal: Finnish-Soviet Artistic Networks in Context Simo Mikkonen, U of Jyväskylä (Finland);

Global Citizens Defy Star Wars: How Spacebridges Promoted Star Peace

Jennifer Hudson, U of Texas at Dallas 
B.

"Revolution from Abroad and Internal Dissension: Émigré Anti-Communism and the Cold War"

Chair: Jennifer Hudson, U of Texas at Dallas

Discussant: Laurie Manchester, Arizona State U

Soviet Emigres and Old Russian Socialists during the Cold War: Hopes and Disappointments

Alexey Antoshin, Ural Federal U (Russia);

Judgment in Moscow? Returning Dissenters and the Struggle for Political Authority in Moscow and Kiev, 1987-1991.

Manfred Zeller, Bremen U;

Emigre Anti-Communism meets American Philanthropy: The Ford Foundation's East European Fund, 1950-1955

Benjamin Tromly, U of Puget Sound

C.

"Religious dimension of Russian-American imagology: from the Tsarist Empire to Putin's Russia"

Chair: Lee Farrow, Auburn U at Montgomery

Discussant: David Holloway, Stanford University

How did religion frame American perception of the Late Tsarist Empire

Victoria Zhuravleva, Russian State U for the Humanities (Russia);

Religious aspect of the Soviet dissident movement in representations of the US media

Nadezhda Azhghikina, Lomonosov Moscow State U (Russia), PEN Moscow;

Mastering the American style: religious motives in the modern Russian political rhetoric

Aleksandr Okun, Samara U (Russia);

D.

"“'Believing in Peace and Freedom: Soviet Citizens and Foreign Friends during the Cold War"',

Roundtable Member: Alexis Peri, Boston U

Roundtable Member: David Foglesong, Rutgers, The State U of New Jersey

Roundtable Member: Christine Varga-Harris, Illinois State U

Roundtable Member: Matthias Neumann, U of East Anglia (UK)

Chair: Choi Chatterjee, California State U, Los Angeles

E.

"American Belief (or not) in the Bolshevik Revolution"

Chair: Lee Farrow, U of Kansas

Roundtable Member: Lee Farrow, Auburn U at Montgomery

Roundtable Member: Matt Miller, U of Northwestern-St. Paul

Roundtable Member: Lyubov Ginzburg, Independent Scholar 
F.

"The New Cold War and the Magnitsky Act"

Chair: Choi Chatterjee, California State University, Los Angeles

Roundtable Member: Mitchell A. Orenstein, University of Pennsylvania

Roundtable Member: Barbara Brigitte Walker, University of Nevada, Reno

Roundtable Member: Denise J. Youngblood, University of Vermont

Roundtable Member: Victoria I. Zhuravleva, Russian State University for the Humanities

CEERES of Voices: Ben Whisenhunt - Slavica Publishers, Americans in Revolutionary Russia Series, with William Nickell - January 26, 2020, 3-4pm - Seminary Coop Bookstore, Chicago, IL.

https://www.semcoop.com/event/ben-whisenhunt-slavica-publishers-americansrevolutionary-russia-series

\section{Three New Books!}

Slavica Publishers has just published three new books in the series, "Americans in Revolutionary Russia," edited by Norman E. Saul and William Benton Whisenhunt.

https://slavica.indiana.edu/series/Americans_in_Revolutionary_Russia 